\title{
AGE DIFFERENCES IN THE ANDROGYNY SCORE
}

\author{
J. S. MILNE* \\ Geriatric Research Unit, Royal Victoria Hospital, Edinburgh
}

It has been suggested that the androgyny score, computed to estimate the degree of femininity of build in the male (Tanner, 1951), diminishes with increasing age (Kelsey, 1965; Henderson and Dugard, 1968). This paper describes age differences in the androgyny score in a cross-sectional study of men and women aged $20-90$ years.

\section{MeTHODS}

The sample examined consisted of 413 men and 406 women aged 20-90 years. This sample was obtained in two parts. The first contained 215 men and 272 women aged 62-90 years, who formed a simple random sample of the 27,000 older people living in a defined area of Edinburgh. The method of sampling these subjects, who are taking part in a longitudinal study of ageing persons, has been described elsewhere (Milne, Maule, and Williamson, 1971). The second part was composed of 198 men and 134 women aged 20-65 years, who were donors providing blood at the Regional Blood Transfusion Service in Edinburgh. I attended donor sessions and circulated a leaflet requesting volunteers for anthropometry. More people volunteered than could be measured in the time available. Bias was introduced by the Blood Transfusion Service policy of rejecting donors under 5 feet $(1.5 \mathrm{~m})$ in height or 8 stone $(50.8 \mathrm{~kg})$ in weight. This sample, although not random, is from the population living in Edinburgh. The distribution of Landsteiner blood groups in the samples of older people and of blood donors, who were measured, did not differ significantly from that published for Edinburgh (Kopéc, 1970). In this respect, therefore, the samples do not differ from the population of Edinburgh. The age distribution of the combined samples of older people and blood donors is given in Table $I$.

Measurements of biacromial (BAD) and bi-iliac (BID) diameters were made from behind with the subjects standing, using the Harpenden anthropometer (Tanner and Whitehouse, 1957). Care was taken that the shoulders were in a relaxed position when measuring BAD, and that firm pressure was exerted with the branches of the anthropometer when measuring BID. The right suprailiac skinfold thickness was measured using the Harpenden caliper as described by Tanner (1959).

- Present address: MRC Clinical and Population Cytogenetics Unit, Western General Hospital, Edinburgh.
TABLE I

AGE AND SEX DISTRIBUTION OF SAMPLE

\begin{tabular}{cc|c|c}
\hline & $\begin{array}{c}\text { Age } \\
\text { Range }\end{array}$ & Men & Women \\
\hline $\begin{array}{c}20-24 \\
25-29\end{array}$ & 33 & 37 \\
$30-34$ & 28 & 19 \\
$35-39$ & 30 & 18 \\
$40-44$ & 15 & 11 \\
$45-49$ & 17 & 11 \\
$50-54$ & 20 & 13 \\
& $55-59$ & 12 & 8 \\
& $60-64$ & 55 & 51 \\
& $65-69$ & 77 & 96 \\
& $70-74$ & 39 & 56 \\
& $75-79$ & 34 & 45 \\
& $>80$ & 20 & 34 \\
\hline & Total & 413 & 406 \\
\hline
\end{tabular}

The androgyny score was calculated as $3 \times \mathrm{BAD}$ minus $1 \times$ BID (Tanner, 1951). Since the diameters were measured in millimetres, the androgyny score is 10 times the figure as originally described by Tanner.

\section{RELIABILITY}

This was studied by measuring the same 12 subjects on two occasions. A reliability coefficient was calculated, using the analysis of variance, by dividing the variance for persons by the sum of the variances due to persons, occasions, and error. Variance due to error was the residual mean square after removing variance due to persons and occasions. Coefficients for the author's variance determined in this way before and after the survey are given in Table II.

TABLE II

INTRA-OBSERVER AND INTER-OBSERVER RELIABILITY STUDIES

\begin{tabular}{|c|c|c|c|c|}
\hline & \multicolumn{3}{|c|}{ Reliability Coefficients } & \multirow{2}{*}{$\begin{array}{c}\text { Number } \\
\text { of } \\
\text { Subjects }\end{array}$} \\
\hline & $\begin{array}{c}\text { Biacromial } \\
\text { Diameter }\end{array}$ & $\begin{array}{c}\text { Bi-iliac } \\
\text { Diameter }\end{array}$ & $\begin{array}{l}\text { Suprailiac } \\
\text { Skinfold }\end{array}$ & \\
\hline $\begin{array}{l}\text { One observer } \\
\text { Before survey } \\
\text { After survey }\end{array}$ & $\begin{array}{l}0.98 \\
0.98\end{array}$ & $\begin{array}{l}0.85 \\
0.96\end{array}$ & $\begin{array}{l}0.98 \\
0.93\end{array}$ & $\begin{array}{l}12 \\
12\end{array}$ \\
\hline Two observers & 0.86 & 0.88 & - & 12 \\
\hline
\end{tabular}


An inter-observer study was carried out by the author and another observer measuring another 12 subjects on one occasion. Measurements were made so that one observer did not see the other at work. The coefficient was calculated with variance due to observers substituted for variance due to occasions. The results of this study (BAD and BID only) are also shown in Table II.

In the analysis of variance, the contributions to the total variance made by persons and occasions were examined using the $F$ test. In all variables in the inter-observer and intra-observer studies the ratio of mean square for persons to mean square for error was significant at the $1 \%$ level. The corresponding ratio for occasions was significant only for bi-iliac diameter in 1970 and that just reached the $5 \%$ level. With this exception the principal contributor to the total variance was persons, and the observations can be accepted as reproducible.

\section{RESULTS}

Frequency distributions of androgyny score, BAD, and BID are given by decade for men and women separately in Figures 1, 2, and 3. For ease
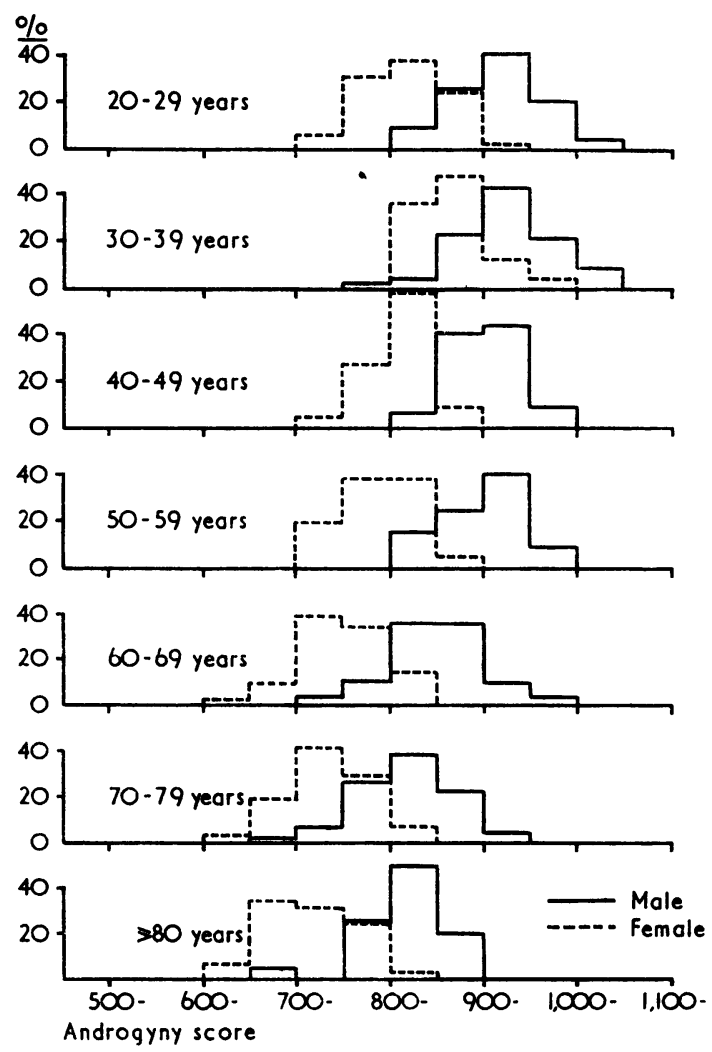

Fig. 1. Frequency distribution of androgyny score (percentages) by decade in men and women. of comparison the values used are percentages. The modal value of androgyny score and BAD in both $\stackrel{\square}{\circ}$ sexes decreases in persons of 60 years and over, while the modal value of BID is greater in older people. $\stackrel{\vec{S}}{\rightarrow}$

Mean values of the three variables with standard 0 deviations and standard errors are given in five-year $\frac{\bar{\sigma}}{\bar{N}}$ age groups in Table III. Inspection suggests little $\frac{\omega}{T}$ change in androgyny score or BAD in the age range $\stackrel{\odot}{\varnothing}$ from 20 to the fifties. Women thereafter show a gradual diminution in mean values up to old age $\overrightarrow{0}$ but men have a sharp fall in mean values from the fifties to the mid-seventies and thereafter the fall $\vec{\omega}$ levels off. The mean values of BID in both sexes increase gradually from 20 years of age to the fifties, after which the values seem relatively constant.

These age differences have been described using linear regressions. For each of the three variables, in is women, two regression lines have been computed, $\stackrel{\omega}{-}$ one from 20 to 49 years and the other from 50 years $ᄋ$ to old age. In men, similar lines have been used for the regression of BID on age, but for androgyny $z$ score and BAD three lines were used covering age ranges $20-59,55-74$, and $70->80$ years. The age ranges
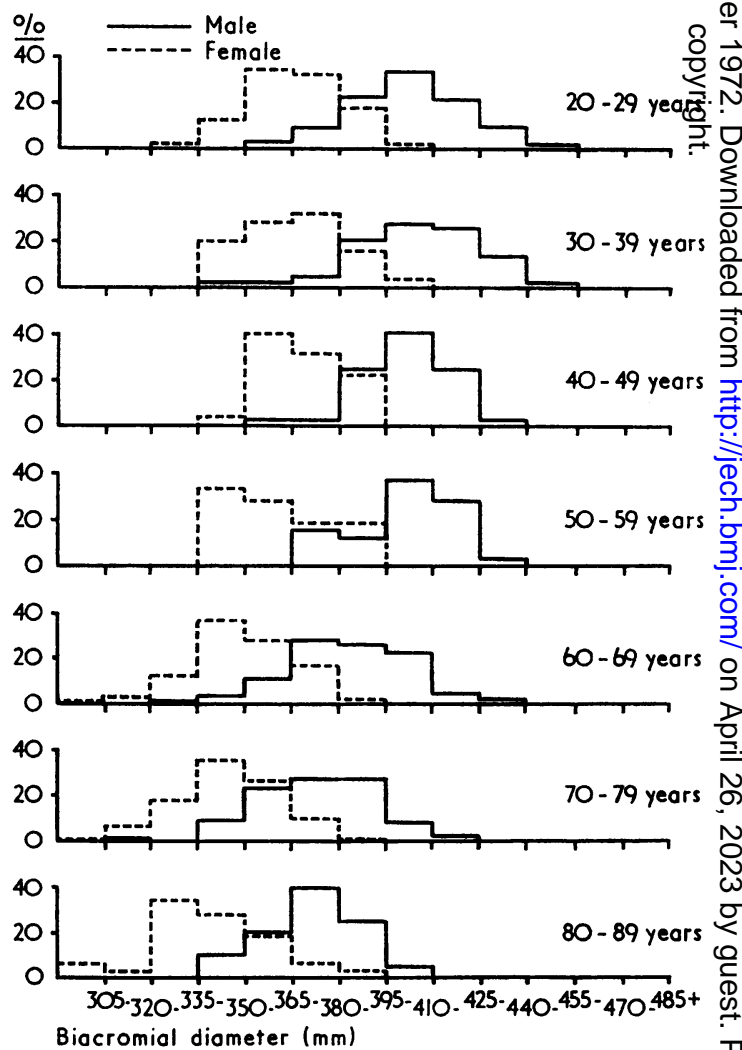

FIG. 2. Frequency distribution (percentages) of biacromial diameter $\bar{O}$ by decade in men and women. 

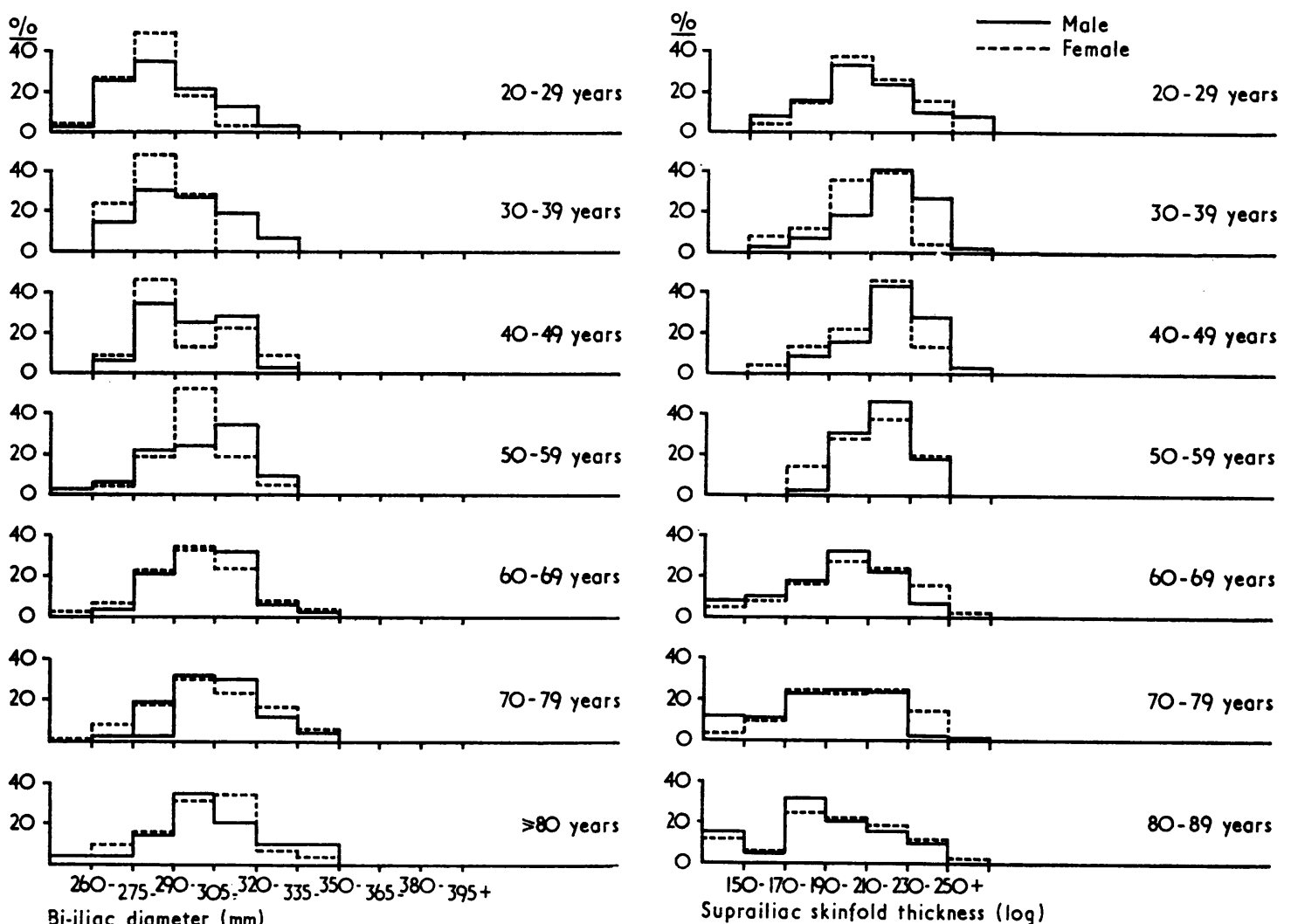

Fig. 3. Frequency distribution (percentages) of bi-iliac diameter by decade in men and women.

Fig. 4. Frequency distribution (percentages) of right suprailiac skinfold thickness (log transformation) in men and women.

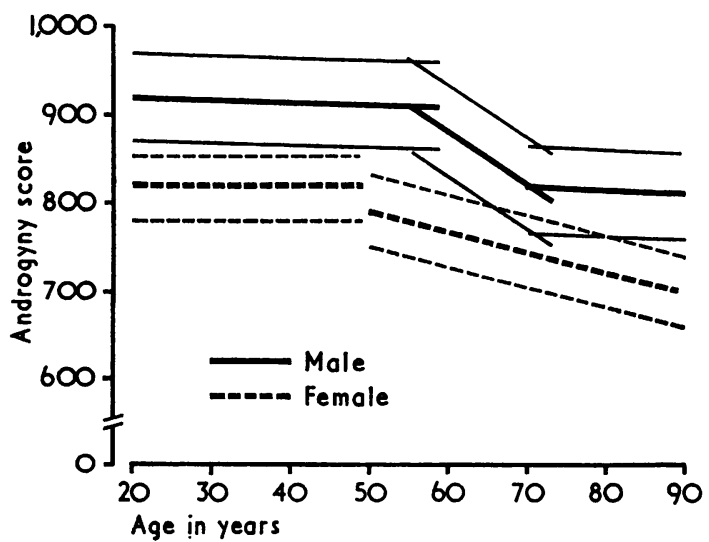

Fig. 5. Regression of androgyny score on age in men and women ( 1 standard error).

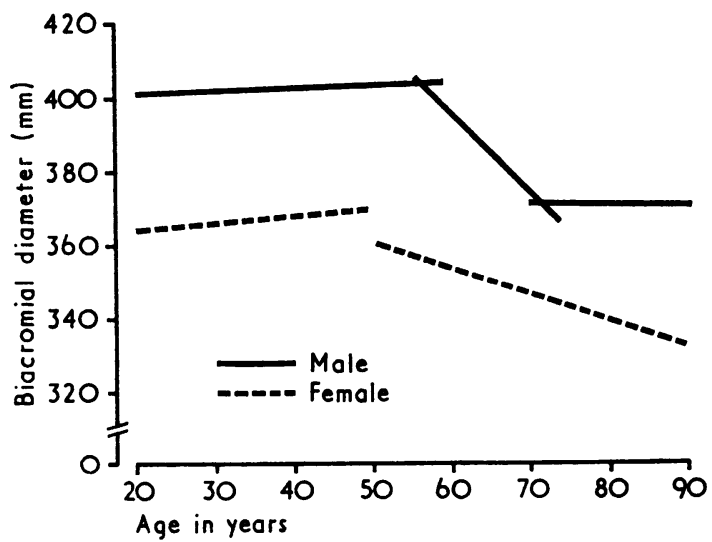

FIG. 6. Regression of biacromial diameter on age in men and women. 
TABLE III

1

MEAN VALUES WITH STANDARD DEVIATIONS AND STANDARD ERRORS FOR ANDROGYNY SCORE AND RELATED VARIABLES IN MEN AND WOMEN

\begin{tabular}{|c|c|c|c|c|c|c|c|c|c|c|c|c|c|}
\hline \multirow{2}{*}{$\begin{array}{c}\text { Age } \\
\text { Range }\end{array}$} & \multicolumn{3}{|c|}{ Androgyny Score } & \multicolumn{3}{|c|}{$\begin{array}{c}\text { Biacromial } \\
\text { Diameter (mm) }\end{array}$} & \multicolumn{3}{|c|}{$\begin{array}{c}\text { Bi-iliac } \\
\text { Diameter (mm) }\end{array}$} & \multicolumn{3}{|c|}{$\begin{array}{c}\text { Suprailiac } \\
\text { Skinfold (log) }\end{array}$} & \multirow[b]{2}{*}{$\mathbf{N}$} \\
\hline & Mean & SD & SE & Mean & SD & SE & Mean & SD & SE & Mean & SD & $\mathbf{S E}$ & \\
\hline $\begin{array}{l}\text { Men } \\
20-24 \\
25-29 \\
30-34 \\
35-39 \\
40-44 \\
45-49 \\
50-54 \\
55-59 \\
60-64 \\
65-69 \\
70-74 \\
75-79 \\
>80\end{array}$ & $\begin{array}{l}908 \\
927 \\
928 \\
916 \\
892 \\
916 \\
906 \\
922 \\
857 \\
843 \\
815 \\
815 \\
811\end{array}$ & $\begin{array}{l}52 \cdot 3 \\
41 \cdot 1 \\
47 \cdot 4 \\
54 \cdot 1 \\
40 \cdot 6 \\
35 \cdot 4 \\
49 \cdot 4 \\
83 \cdot 4 \\
48 \cdot 5 \\
53 \cdot 1 \\
54 \cdot 9 \\
45 \cdot 2 \\
43 \cdot 5\end{array}$ & $\begin{array}{r}9 \cdot 1 \\
7 \cdot 2 \\
9 \cdot 0 \\
9 \cdot 9 \\
10 \cdot 5 \\
8 \cdot 6 \\
11 \cdot 1 \\
24 \cdot 1 \\
6 \cdot 6 \\
6 \cdot 1 \\
8 \cdot 9 \\
7 \cdot 8 \\
9 \cdot 7\end{array}$ & $\begin{array}{l}397 \cdot 9 \\
404 \cdot 7 \\
406 \cdot 5 \\
403 \cdot 2 \\
396 \cdot 9 \\
404 \cdot 9 \\
400 \cdot 2 \\
408 \cdot 5 \\
386 \cdot 2 \\
380 \cdot 9 \\
371 \cdot 5 \\
374 \cdot 1 \\
371 \cdot 1\end{array}$ & $\begin{array}{l}20 \cdot 5 \\
16 \cdot 2 \\
18 \cdot 3 \\
20 \cdot 6 \\
18 \cdot 1 \\
12 \cdot 7 \\
17.4 \\
27 \cdot 7 \\
18 \cdot 9 \\
19 \cdot 6 \\
19 \cdot 6 \\
18 \cdot 6 \\
15 \cdot 3\end{array}$ & $\begin{array}{l}3 \cdot 6 \\
2 \cdot 8 \\
3 \cdot 5 \\
3 \cdot 8 \\
4 \cdot 7 \\
3 \cdot 1 \\
3 \cdot 9 \\
8 \cdot 0 \\
2 \cdot 6 \\
2 \cdot 2 \\
3 \cdot 2 \\
3 \cdot 2 \\
3 \cdot 4\end{array}$ & $\begin{array}{l}285 \cdot 5 \\
286 \cdot 5 \\
291 \cdot 3 \\
293 \cdot 2 \\
298 \cdot 5 \\
299 \cdot 1 \\
294 \cdot 5 \\
303 \cdot 4 \\
301 \cdot 5 \\
299 \cdot 6 \\
299 \cdot 1 \\
307 \cdot 3 \\
302 \cdot 8\end{array}$ & $\begin{array}{l}23 \cdot 4 \\
23 \cdot 9 \\
16 \cdot 2 \\
17 \cdot 0 \\
31 \cdot 2 \\
17 \cdot 5 \\
17 \cdot 2 \\
16 \cdot 5 \\
16 \cdot 1 \\
14 \cdot 3 \\
13 \cdot 4 \\
19 \cdot 5 \\
21 \cdot 9\end{array}$ & $\begin{array}{l}4 \cdot 1 \\
4 \cdot 2 \\
3 \cdot 1 \\
3 \cdot 1 \\
8 \cdot 1 \\
4 \cdot 2 \\
3 \cdot 9 \\
4 \cdot 9 \\
2 \cdot 2 \\
1 \cdot 6 \\
2 \cdot 2 \\
3 \cdot 2 \\
4 \cdot 9\end{array}$ & $\begin{array}{l}203 \\
209 \\
216 \\
220 \\
214 \\
224 \\
212 \\
224 \\
193 \\
195 \\
183 \\
196 \\
188\end{array}$ & $\begin{array}{l}25 \cdot 7 \\
23 \cdot 2 \\
21 \cdot 8 \\
18 \cdot 4 \\
21 \cdot 3 \\
16 \cdot 7 \\
14 \cdot 2 \\
12 \cdot 8 \\
30 \cdot 0 \\
30 \cdot 2 \\
30 \cdot 5 \\
29 \cdot 5 \\
32 \cdot 8\end{array}$ & $\begin{array}{l}4 \cdot 5 \\
4 \cdot 0 \\
4 \cdot 1 \\
3 \cdot 4 \\
5 \cdot 5 \\
4 \cdot 0 \\
3 \cdot 2 \\
3 \cdot 7 \\
4 \cdot 1 \\
3 \cdot 4 \\
4 \cdot 9 \\
5 \cdot 1 \\
7 \cdot 5\end{array}$ & $\begin{array}{l}33 \\
33 \\
28 \\
30 \\
15 \\
17 \\
20 \\
12 \\
54 \\
77 \\
38 \\
34 \\
20\end{array}$ \\
\hline $\begin{array}{c}\text { Women } \\
20-24 \\
25-29 \\
30-34 \\
35-39 \\
40-44 \\
45-49 \\
50-54 \\
55-59 \\
60-64 \\
65-69 \\
70-74 \\
75-79 \\
>80\end{array}$ & $\begin{array}{l}818 \\
815 \\
817 \\
812 \\
813 \\
816 \\
801 \\
778 \\
756 \\
743 \\
735 \\
726 \\
716\end{array}$ & $\begin{array}{l}40 \cdot 4 \\
44 \cdot 4 \\
39 \cdot 1 \\
38 \cdot 0 \\
38 \cdot 6 \\
29 \cdot 7 \\
41 \cdot 9 \\
39 \cdot 0 \\
36 \cdot 0 \\
42 \cdot 6 \\
40 \cdot 8 \\
49 \cdot 7 \\
48 \cdot 2\end{array}$ & $\begin{array}{r}6 \cdot 6 \\
10 \cdot 2 \\
9 \cdot 2 \\
14 \cdot 4 \\
11 \cdot 6 \\
9 \cdot 0 \\
11 \cdot 6 \\
13 \cdot 8 \\
5 \cdot 1 \\
4 \cdot 4 \\
5 \cdot 5 \\
7 \cdot 5 \\
8 \cdot 5\end{array}$ & $\begin{array}{l}365 \cdot 4 \\
367 \cdot 0 \\
366 \cdot 3 \\
362 \cdot 9 \\
369 \cdot 4 \\
369 \cdot 6 \\
367 \cdot 1 \\
355 \cdot 5 \\
351 \cdot 4 \\
347 \cdot 1 \\
346 \cdot 3 \\
342 \cdot 0 \\
338 \cdot 7\end{array}$ & $\begin{array}{r}14 \cdot 6 \\
16 \cdot 1 \\
15 \cdot 9 \\
14 \cdot 0 \\
16 \cdot 3 \\
9 \cdot 9 \\
15 \cdot 2 \\
13 \cdot 3 \\
13 \cdot 5 \\
16 \cdot 9 \\
14 \cdot 8 \\
19 \cdot 3 \\
18 \cdot 8\end{array}$ & $\begin{array}{l}2 \cdot 4 \\
3 \cdot 7 \\
3 \cdot 8 \\
5 \cdot 3 \\
4 \cdot 9 \\
3 \cdot 0 \\
4 \cdot 2 \\
4 \cdot 7 \\
1 \cdot 9 \\
1 \cdot 8 \\
2 \cdot 0 \\
2 \cdot 9 \\
3 \cdot 3\end{array}$ & $\begin{array}{l}278 \cdot 4 \\
285 \cdot 5 \\
282 \cdot 5 \\
276 \cdot 7 \\
294 \cdot 6 \\
292 \cdot 6 \\
300 \cdot 5 \\
289 \cdot 5 \\
298 \cdot 6 \\
298 \cdot 6 \\
303 \cdot 7 \\
300 \cdot 1 \\
300 \cdot 5\end{array}$ & $\begin{array}{l}12 \cdot 9 \\
16 \cdot 6 \\
12 \cdot 1 \\
10 \cdot 8 \\
14 \cdot 6 \\
20 \cdot 1 \\
12 \cdot 3 \\
14.9 \\
17 \cdot 6 \\
19 \cdot 7 \\
18 \cdot 7 \\
19 \cdot 2 \\
17 \cdot 6\end{array}$ & $\begin{array}{l}2 \cdot 1 \\
3 \cdot 8 \\
2 \cdot 8 \\
4 \cdot 1 \\
4 \cdot 4 \\
6 \cdot 1 \\
3 \cdot 4 \\
5 \cdot 3 \\
2 \cdot 5 \\
2 \cdot 0 \\
2 \cdot 5 \\
2 \cdot 5 \\
3 \cdot 1\end{array}$ & $\begin{array}{l}207 \\
206 \\
204 \\
200 \\
210 \\
209 \\
212 \\
213 \\
202 \\
201 \\
203 \\
195 \\
194\end{array}$ & $\begin{array}{l}19 \cdot 1 \\
23 \cdot 8 \\
22 \cdot 4 \\
25 \cdot 7 \\
22 \cdot 5 \\
16 \cdot 9 \\
17 \cdot 4 \\
21 \cdot 6 \\
26 \cdot 3 \\
32 \cdot 4 \\
26 \cdot 0 \\
27 \cdot 4 \\
31 \cdot 1\end{array}$ & $\begin{array}{l}3 \cdot 1 \\
5 \cdot 5 \\
5 \cdot 3 \\
9 \cdot 7 \\
6 \cdot 8 \\
5 \cdot 1 \\
4 \cdot 8 \\
7 \cdot 6 \\
3 \cdot 7 \\
3 \cdot 3 \\
3 \cdot 5 \\
4 \cdot 1 \\
5 \cdot 5\end{array}$ & $\begin{array}{r}37 \\
19 \\
18 \\
7 \\
11 \\
11 \\
13 \\
8 \\
51 \\
94 \\
55 \\
44 \\
32\end{array}$ \\
\hline
\end{tabular}

Data missing in 2 men and 6 women

TABLE IV REGRESSIONS OF ANDROGYNY SCORE AND RELATED VARIABLES ON AGE IN MEN AND WOMEN

\begin{tabular}{|c|c|c|c|c|c|c|c|}
\hline Sex and Age Range & Constant & $\begin{array}{l}\text { Regression } \\
\text { Coefficient } \\
\text { (age) }\end{array}$ & $\begin{array}{c}\text { S.E.E. } \\
\text { Regression } \\
\text { Coefficient }\end{array}$ & $\begin{array}{c}\text { SE } \\
\text { of } \\
\text { Regression }\end{array}$ & $\begin{array}{c}\text { Mean of } \\
\text { Dependent } \\
\text { Variable }\end{array}$ & $\begin{array}{c}\text { Mean } \\
\text { Age }\end{array}$ & $\mathbf{N}$ \\
\hline \multirow{2}{*}{$\begin{array}{l}\text { ANDROGYNY SCORE } \\
\text { Men } \\
20-59 \\
55-74 \\
70-\frac{1}{\text { Tomen }}>80 \\
20-49 \\
50->80\end{array}$} & $\begin{array}{r}+925.3325 \\
+1236.6282 \\
+844.2635\end{array}$ & $\begin{array}{l}-0.2605 \\
=5.9085^{* *} \\
-0.3956\end{array}$ & $\begin{array}{l}0.3360 \\
0.9695 \\
1.0326\end{array}$ & $\begin{array}{l}50.4 \\
54.4 \\
48.9\end{array}$ & $\begin{array}{l}916 \\
847 \\
814\end{array}$ & $\begin{array}{l}36 \cdot 0 \\
66.0 \\
76 \cdot 1\end{array}$ & $\begin{array}{r}188 \\
181 \\
92\end{array}$ \\
\hline & $\begin{array}{r}+817.6824 \\
+898.0156\end{array}$ & $\begin{array}{l}-0.0556 \\
-2.2435^{* *}\end{array}$ & $\begin{array}{l}0.4450 \\
0.3127\end{array}$ & $\begin{array}{r}38.9 \\
42 \cdot 8 \\
\end{array}$ & $\begin{array}{l}816 \\
742\end{array}$ & $\begin{array}{l}30 \cdot 3 \\
69 \cdot 7 \\
\end{array}$ & $\begin{array}{l}103 \\
297 \\
\end{array}$ \\
\hline \multirow{2}{*}{$\begin{array}{l}\text { BIACROMIAL DIAMETER } \\
\text { Men } \\
20-59 \\
55-74 \\
70->80 \\
\text { Women } \\
20-49 \\
50->80\end{array}$} & $\begin{array}{r}+400 \cdot 1670 \\
+517.9582 \\
+375.0335\end{array}$ & $\begin{array}{l}+0.0701 \\
-2.0550 * * \\
-0.0351\end{array}$ & $\begin{array}{l}0 \cdot 1262 \\
0 \cdot 3543 \\
0 \cdot 3861\end{array}$ & $\begin{array}{l}18.9 \\
19 \cdot 9 \\
18 \cdot 3\end{array}$ & $\begin{array}{l}402 \cdot 7 \\
382 \cdot 4 \\
372 \cdot 4\end{array}$ & $\begin{array}{l}36 \cdot 0 \\
66 \cdot 0 \\
76 \cdot 1\end{array}$ & $\begin{array}{r}188 \\
181 \\
92\end{array}$ \\
\hline & $\begin{array}{r}+361.7358 \\
+395.9972\end{array}$ & $\stackrel{+0.1581}{-0.7014 * *}$ & $\begin{array}{l}0 \cdot 1673 \\
0 \cdot 1199\end{array}$ & $\begin{array}{l}14.6 \\
16.4\end{array}$ & $\begin{array}{l}366 \cdot 5 \\
347 \cdot 1\end{array}$ & $\begin{array}{l}30 \cdot 3 \\
69 \cdot 7\end{array}$ & $\begin{array}{l}103 \\
297\end{array}$ \\
\hline \multirow{2}{*}{$\begin{array}{l}\text { Bi-ILIAC DIAMETER } \\
\text { Men } \\
20-49 \\
50-\frac{1}{50}>80 \\
\text { Women } \\
20-49 \\
50->80\end{array}$} & $\begin{array}{r}+270.9997 \\
+285.4072\end{array}$ & $\begin{array}{l}+0.6153 * * \\
+0.2303\end{array}$ & $\begin{array}{l}0 \cdot 2070 \\
0 \cdot 1256\end{array}$ & $\begin{array}{l}21 \cdot 3 \\
16 \cdot 3\end{array}$ & $\begin{array}{l}291 \cdot 0 \\
301 \cdot 0\end{array}$ & $\begin{array}{l}32.4 \\
67.7\end{array}$ & $\begin{array}{l}156 \\
255\end{array}$ \\
\hline & $\begin{array}{r}+267.5252 \\
+289.9760\end{array}$ & $\begin{array}{l}+0.5298 * * \\
+0.1393\end{array}$ & $\begin{array}{l}0 \cdot 1681 \\
0 \cdot 1350\end{array}$ & $\begin{array}{l}14.7 \\
18.5\end{array}$ & $\begin{array}{l}283.6 \\
299.7\end{array}$ & $\begin{array}{l}30 \cdot 3 \\
69 \cdot 7 \\
\end{array}$ & $\begin{array}{l}103 \\
297 \\
\end{array}$ \\
\hline \multirow{2}{*}{$\begin{array}{l}\text { SUPraIIIAC SKINFOLD (LC } \\
\text { Men } \\
20-49 \\
50->80 \\
\text { Women } \\
20-49 \\
50->80\end{array}$} & $\begin{array}{r}+195.0661 \\
+243.7765\end{array}$ & $\begin{array}{l}+0.5085 * \\
-0.7585^{* *}\end{array}$ & $\begin{array}{l}0.2169 \\
0.2277\end{array}$ & $\begin{array}{l}22 \cdot 3 \\
29 \cdot 5\end{array}$ & $\begin{array}{l}212 \\
192\end{array}$ & $\begin{array}{l}32 \cdot 4 \\
67 \cdot 6\end{array}$ & $\begin{array}{l}156 \\
255\end{array}$ \\
\hline & $\begin{array}{r}+201.2777 \\
+235.3916\end{array}$ & $\begin{array}{l}+0.1317 \\
-0.5016^{*}\end{array}$ & $\begin{array}{l}0 \cdot 2419 \\
0.1987\end{array}$ & $\begin{array}{l}21 \cdot 1 \\
27 \cdot 2\end{array}$ & $\begin{array}{l}205 \\
200\end{array}$ & $\begin{array}{l}30 \cdot 3 \\
69 \cdot 7\end{array}$ & $\begin{array}{l}103 \\
298\end{array}$ \\
\hline
\end{tabular}




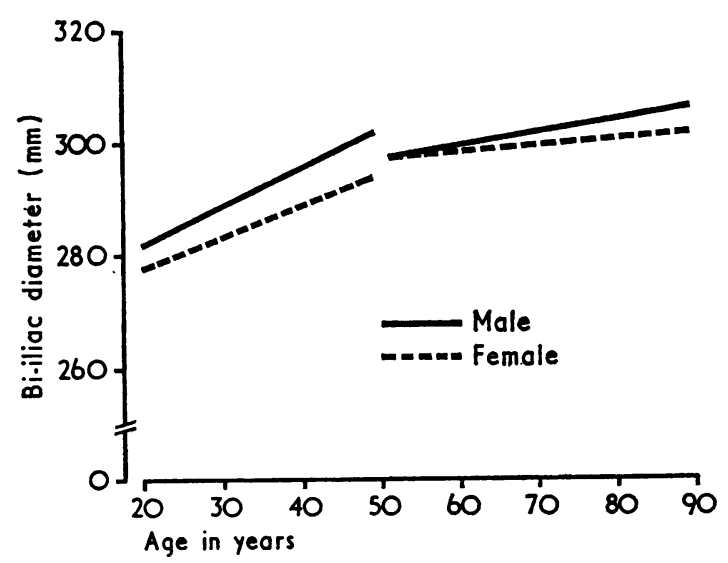

FIG. 7. Regression of bi-iliac diameter on age in men and women.

used in the regression of these dependent variables on age were selected by examining the table of five-year means (Table III) to discover the age ranges with the greatest and least variation for each dependent variable.

The regressions of androgyny score, BAD, and BID on age are given in Table IV and in Figures 5, 6 , and 7. For androgyny score and BAD in women, the regression coefficients for age are significant in the age range 50 to old age but not in the age range 20-49. In men these coefficients are significant in the range 55-74 years but not in age ranges 20-59 and 70 to old age. In men and women the regression coefficient for age in respect of BID is significant in the age range $20-49$ but not in older people.

The fall in BAD and the rise in BID with increasing age both tend to lower the androgyny score. The rise in BID with age might be due to increasing obesity. This possibility was investigated by measuring the right suprailiac skinfold thickness. Five-year means of the log transformation of this variable (Edwards et al., 1955) are reported in Table III and its regression on age in Table IV for age ranges 20-49 and 50 to old age (Figure 8). This analysis reveals an increase in the skinfold thickness with increasing age in men, but not in women, up to age 50. Thereafter in both sexes the fall with increasing age is significant. At ages when the androgyny score is falling in value and the BID appears constant, the suprailiac skinfold thickness is also decreasing (Figure 8).

\section{Discussion}

This cross-sectional study confirms that there is an age difference in the androgyny score, the decrease in both sexes beginning in the fifties. A sex difference is also present in that the score in women continues to fall up to old age, while in men a steep fall in the

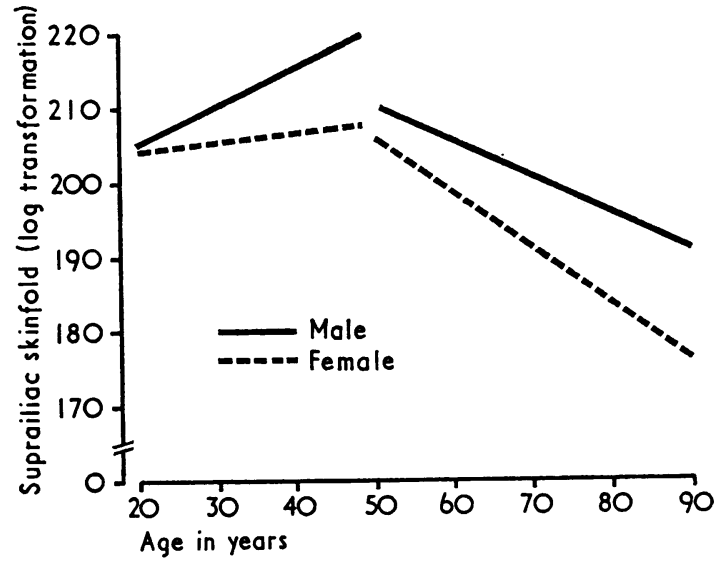

FIG. 8. Regression of right suprailiac skinfold thickness (log transformation) on age in men and women.

years 55-74 levels off in old age. Because the study is cross-sectional, the differences found are likely to have been greatly influenced by the effects of mortality. The mortality rates for 1969 in Scotland for men aged 55-64 and 65-74 are respectively $24 \cdot 7$ and 59.2 per 1,000 , the corresponding figures in women being 12.9 and 32.9 (Registrar General for Scotland, 1971). It is possible that an association between this greater mortality, in men compared with women, and the androgyny score in these age groups explains the steep fall, found in men only, in the regression of androgyny on age from 55-74 years. Figure 5 shows that the men who survive this period tend towards 'femaleness' as measured by the androgyny score. Greater 'maleness' as measured by this score may militate against survival in middle age.

Some support is given to this hypothesis by the author's unpublished data concerning men, in the present study, aged 62-74 years. These men form part of the sample being studied longitudinally and have had a full clinical examination including electrocardiography. No comparable information is available about men younger than 62 who were blood donors not studied in such detail. The men aged 62-74 can be divided into those with probable and possible ischaemic heart disease, as defined by Reid, Holland, Humerfelt, and Rose (1966), and those with no evidence of such disease. The mean androgyny score in 20 men with probable ischaemic heart disease is 855 (SE 11.3) compared with 836 (SE 5.1) in 106 men with no evidence of such disease. The possible group has a mean value between these figures. Although the confidence limits of these means overlap, possibly because of small sample sizes, the figures suggest that during the age period where the regression line of androgyny on age falls steeply, men with a disease known to be an 
important contributor to middle-aged mortality have a higher mean androgyny score than men with no evidence of this disease. Longitudinal study would be needed to examine properly this apparent association between maleness, measured by the androgyny score, and middle-aged mortality. Such a study would also show whether the age differences described in this paper overestimate age changes.

With increasing age, biacromial diameter and bi-iliac diameter both show differences in directions which lower the androgyny score. The bi-iliac diameter, after increasing up to age 50, remains constant thereafter. The fall in the androgyny score in older people is therefore due to a decrease in the biacromial diameter. The constancy of the bi-iliac diameter in persons above 50 years of age and the decrease in suprailiac skinfold thickness in this age group suggest that an increase in bi-iliac diameter due to obesity is not an important cause of the lower androgyny scores in older people. Kelsey (1965) showed in the relatives of schizophrenic patients that an increase with age in bi-iliac diameter was not associated with an increase in weight.

Androgyny score has been studied in relation to mental illness (Ray and Coppen, 1959; Kelsey, 1965; Henderson and Dugard, 1968; Price, 1969) and to sexual disorders (Coppen, 1959: Johnston, 1965). Men who were hypogonadal or who had female sex chromatin were found to have decreased biacromial diameters (Raboch, 1957) while women with hirsuties and increased urinary 17-ketosteroid excretion had an increase in this measurement (Ferriman, Thomas, and Purdie, 1957). The findings in respect of age differences in the present study emphasize the need, mentioned by Kelsey, to allow for age when relating any disorder to the androgyny score.

Measurement figures in the present study agree fairly well with control figures given by other authors (Ray and Coppen, 1959; Kelsey, 1965; Johnston, 1965). One large study (Board of Trade, 1957) in women, of anthropometry in relation to clothing sizes, included the biacromial but not the bi-iliac diameter. In women aged 20-54, the BAD was found to be very close to $350 \mathrm{~mm}$. In corresponding fiveyear age groups this figure is $15-20 \mathrm{~mm}$ less than in the present study. The Board of Trade report gives a clear description of how the BAD was measured but does not mention any instruction to make the measurement with the shoulders of the subject relaxed. This difference in technique may explain the difference in results.

The fall in the androgyny score as age increases may result from changes in the shape of the thorax. The anteroposterior diameter of the thorax is known to increase and the transverse diameter to diminish with increasing age. Increase in anteroposterior diameter is associated with increased kyphosis, in turn associated with changes in the shape of vertebral bodies resulting from senile osteoporosis. These vertebral changes begin after 50 years in women and after 60 years in men. The effect of the change in shape of the thorax is to bring the scapulae closer together with a decrease in biacromial diameter and androgyny score.

\section{SUMMARY}

The androgyny score was calculated from biacromial and bi-iliac diameters measured in Edinburgh in $\mathbf{4 1 3}$ men and $\mathbf{4 0 6}$ women aged 20-90. The score showed a fall in both sexes beginning in the fifties. The fall was gradual in women and steeper, with later levelling off, in men. The steep fall in men may be associated with increased mortality among those men with greater degrees of maleness as measured by the androgyny score. Reduction in biacromial diameter was the main factor in the fall of the score. Larger bi-iliac diameters in older people were not associated with increased subcutaneous fat.

I wish to thank Dr. J. Williamson (Director, Geriatrie Research Unit), Dr. R. A. Cumming and Dr. A. Es Robertson of the Regional Blood Transfusion Service Edinburgh, for allowing access to donors and providing accommodation for measurement, Dr. Keith Hope (Fellow of Nuffield College, Oxford) for help with reliability studies, Mr. Ian J. Lauder (MRC Clinical and Population Cytogenetics Unit, Edinburgh) for help with statistical analysis, and Staff Nurse S. Cormack (Royal Victoria Hospital, Edinburgh) for help in carrying out the measurements.

This work was supported by a grant from the Secretary of State for Scotland via the Advisory Committee on Medical Research.

\section{REFERENCES}

BOARD OF TRADE (1957). Women's Measurements and Sizes. H.M.S.O., London.

COPPEN, A. J. (1959). Body-build of male homosexuals Brit. med. J., 2, 1443.

Edwards, D. A. W., Hammond, W. H., Healy, M. J. R., TANNER, J. M., and Whitehouse, R. H. (1955). Design and accuracy of calipers for measuring subcutaneous tissue thickness. Brit. J. Nutr., 9, 133.

Ferriman, D., Thomas, P. K., and Purdie, A. W. (1957). Constitutional virilism. Brit. med. J., 2, 1410.

Henderson, A. S., and Dugard, P. (1968). Androgyny in adolescent psychiatric patients and in delinquents. Brit. J. prev. soc. Med., 22, 223.

Johnston, J. (1965). Androgyny and disorders of sexual potency. Brit. med. J., 2, 572. 
KeLseY, F. D. (1965). Androgyny in schizophrenics and their relatives. Brit. J. Psychiat., 111, 1159.

Kopéc, A. C. (1970). The Distribution of the Blood Groups in the United Kingdom. Oxford University Press, London.

Mirne, J. S., Maule, M. M., and Williamson, J. (1971). Method of sampling in a study of older people with a comparison of respondents and nonrespondents. Brit. J. prev. soc. Med., $25,37$.

PrICE, J. (1969). An anthropometric comparison of psychiatric patients and their siblings. Brit. J. Psychiat., 115, 435.

RABOCH, J. (1957). Thirty-one men with female sex chromatin. J. clin. Endocr., 17, 1429.
RAY, J. H., and COPPEN, A. J. (1959). Distribution of androgyny in mental patients. Brit. med. J., 2, 1445.

Registrar General fOR Scotland (1971). Annual Report for 1969. Part I-Mortality Statistics. No. 115. H.M.S.O., Edinburgh.

Reid, D. D., Holland, W. W., Humerfelt, S., and Rose, G. A. (1966). A cardiovascular survey of British postal workers. Lancet, 1, 614.

TANNER, J. M. (1951). Current advances in the study of physique. Lancet, 1, 574.

(1959). The measurement of body fat in man. Proc. Nutr. Soc., 18, 148.

-, and WhIteHouse, R. H. (1957). The Harpenden anthropometer: a counter-type anthropometric caliper. Amer. J. phys. Anthrop., n.s. 15, 277. 